\title{
Context and violence in individual prayers for protection 1
}

D G Firth

Student, Department of Old Testament, University of Pretoria Baptist College, Randburg

\section{ABSTRACT}

\section{Context and violence in individual prayers for protection}

The individual prayers for protection within the Psalter are marked by a consistency in terms of the context supposed and the nature of violence experienced by the psalmists. Consistently, these psalms also assert that the right to retributive violence against the enemies belongs to Yahweh alone. Such a consistent pattern indicates that those responsible for assembling the Book of Psalms intended to model this as the appropriate response for the faithful.

\section{INTRODUCTION}

It is possible to read the psalms at a number of levels. With the rise of form criticism as a dominant method, the focus tended to be on the situation of a given psalm within Israel's cult. Such an approach has allowed us to understand with greater clarity the nature of Israel's worship. However, it also tended to neglect the question of the ways in which the finished Book of Psalms was intended to function. For this reason, a recent trend in studies of the psalms has been to address the issue of the shape and purpose of the finished book ${ }^{2}$. At this stage, there is no necessary agreement as to the direction forward. The proposal of this paper is to suggest that a close reading of the contents of the book will indicate the presence of certain editorial aims which, consciously or unconsciously, were followed by those responsible for the editing of the Psalter. Where such patterns have been followed, we may suggest that the final editors believed that the psalms included in the book represented the types of prayers that should be prayed by the faithful. All psalms would then have some didactic function, even those which are not obviously didactic in and of themselves. We may test this hypothesis by examining the individual prayers for protection, where it shall be argued that we do find a standard response to violence being modelled. It is important to note that we are not concerned with the issue of whether or not the individual psalmists have accurately portrayed their situation. We cannot answer this question. However, we can examine 
relevant psalms in terms of the response they offer to determine whether or not the presence of a standard pattern in response is present. It is the finished text of the psalms that allows us to probe the theology of the editors of the book.

The definition of the Gattung of the individual prayer for protection is not particularly well defined. It is, essentially, a sub-genre within the larger group of the laments of the individual. The distinguishing feature of these psalms is that they reflect a situation of imminent physical violence into which Yahweh is summoned to come and offer protection to the individual. Although Mowinckel ${ }^{3}$ regarded the "I" in these psalms as a figure expressing the lamentation of the nation, there is little to be said in favour of this view. In taking this position, Mowinckel seems to have been particularly influenced by his student Birkeland4, who argued that the "enemies" in the psalms were always foreign nations. Although we cannot review this position in detail here, it seems better to consider the question of the identity of the enemies on a case by case basis. The possibility of the "I" of any given prayer for protection heing an individual Israclite remains, although it would need to be demonstrated in each case. In addition, we would need to recognise that in any relecture followed by the editors, the identity of the "I" may well have changed. For example, some of these psalms may have been originally royal, but the absence of royal rubrics means that for the final editors they were read as being the words of an individual. For our purposes, we shall accept Psalms $3,27,35,55,56,64$ and 143 as being individual prayers for protection that can be examined to determine whether or not there is a consistent editorial policy with respect to the response to violence.

\section{TIIE CONTEXT OF VIOI.ENCE IN TIIE INIDIVIIUUA. PRA YERS FOR PROTECTION}

\subsection{The form of the prayers}

Although it is not strictly necessary that the originating context of violence in the individual prayers for protection be the same, it is notable that even at this level we find considerable consistency. Mowinckel believed that these psalms reflected a situation in which violence was imminent, thus necessitating the intervention of Yahweh so as to provide protection. He further noted that the tone of these psalms was somewhat brighter than other laments ${ }^{5}$ a feature that is apparent from the declarations of confidence in Yahweh that we typically find in them. These declarations of 
confidence are different from the Songs of Trust in that they are related to the specific circumstances of the psalmist. We shall note, however, that Mowinckel's insights need to be modified slightly, both form critically and also in terms of the function of these psalms in the finished book. Nevertheless, his basic position provides a platform to allow our investigation.

We may begin by noting that each of these psalms does indeed perceive violence as an imminent threat. Thus, Psalms 3,27,35,56 and 64 are set in a situation of a group of enemies rising up against the psalmist, and actively pursuing them with the intent of causing physical harm, and probably death. A similar situation is apparent in both Psalms 55 and 143, although it would seem likely that these are references to a particular enemy. These psalms demonstrate considerable variety in terms of the ways in which the problem is described and the order in which it is presented, but at some point every one of them makes an explicit reference to the activity of the enemy and the need for Yahweh's protection.

Psalm 3 may be taken as a representative sample. It is, perhaps, the most straight-forward of these psalms, but the elements that we find in it are present in the other psalms in this group. The elements that we find here can be tested against the other psalms so as to show their consistency with Psalm 3. Apart from the title, the psalm contains three main elements:-

1 An address to Yahweh that describes the present distress (vv 2 - 3).

2 An expression of trust in Yahweh's protective power ( $v v 4-7$ ).

3 An appeal, based on the expressed trust, requesting Yahweh's protection (verses $8-9)^{6}$.

What is particularly notable about this psalm is that it sees the main threat from the enemies as being imminent. Although verse 2 clearly indicates that the enemies are currently active against the psalmist, the nature of the claim attributed to them, that the psalmist will not find safety with Yahweh, is most naturally understood as indicating that their main assault on the psalmist is still perceived as imminent.

Thus far, of course, we are in agreement with Mowinckel. Where we need to modify his basic insight is that from the point of view of the psalmist the threat of physical violence is itself a form of violence due to the distress that it causes at the psychological level ${ }^{7}$. The words attributed to the enemies in verse 3 are a denial of the faith of the psalmist, and their tone is in effect a form of psychological assault. Further, the threat of 
further physical violence is also a form of assault. Thus, although the psalm sees physical violence as imminent, the psalmist testifies already to an experience of present violence.

The psalm also attests a declaration of trust in Yahweh, a declaration that is related to the present oppression. In verse 4 we see Yahweh described as a shield (mägēn), whilst a guaranteed answer of some sort is assumed by verse 5 . These statements of present trust reach their climax in verses $6-7$ with a declaration of the assurance of Yahweh's protection at all times and in all circumstances 8 .

Finally, we note the presence of the appeal to Yahweh in verses 8 9, asking him to provide protection, which in this instance includes acting against the enemy. It is worth noting that deliverance is what is sought first, and only then is action against the enemy requested. Worthy of note, too, is the fact that the retributive violence that is sought is essentially defined by the violence experienced. At this stage, the enemies have only directly acted by means of their speech, and the psalmist's request that Yahweh strike them on the jaw and break their teeth is an application of the principle of the lex ralionis. Yahweh is asked to act against the enemies only in terms of the violence that they themselves have generated.

With this as our starting point, it is possible to note the ways in which the same elements function in the other individual prayers for protection. These psalms generally include the three main elements of Psalm 3, though they present them in slightly different ways and embellish the basic structure to some extent. At this point, we simply need to note the presence of each element.

\subsection{The description of distress}

Obviously, there is a variety in the descriptions of distress that we find here, though the consistent presence of the dimension of verbal assault is of some significance In Psalm 27:11-12 reference is made to besetting enemies and malicious witnesses who seek to attack the psalmist. Psalm $35: 1-4$ is similar to Psalm 3 in that the description of the activities of the enemies is placed at the beginning of the poem. However, the psalmist comes back to the issue at a number of points, notably in verses 11-12 (where the motif of malicious witnesses recurs) and verses 15-169. In both these psalms the enemies are portrayed as being currently at work against the psalmist, although the use of legal metaphors suggests the imminence of a greater threat. This factor is especially clear in verse 4 where it is explicitly stated that the enemies seek the life of the psalmist. Some legal 
language also seems to occur in the description of distress in Psalm 143 as the psalmist asks not to be brought into judgment by Yahweh. The pertinent issue is addressed in verse 3 , where the enemy is said to pursue the psalmist, so that the poet is "crushed to the ground" (dikkä' lä'äreș hăyyātî). The presence of legal language in these psalms is not to be taken as indicating that they belong with the prayers of the accused. Rather, it is used with a range of other images to suggest the imminence of physical violence. In particular, though, the legal metaphor is suggestive of the possibility of further violence because of the fact that the very process of judgment includes the process of punishment. However, these psalms also testify to a present experience of violence, and the false accusation, along with other elements, indicates that the psalmists perceive the threat in and of itself as a form of violence.

Some sort of verbal assault would also seem to be indicated by the descriptions of distress in Psalms 55, 56 and 64, though without the legal allusions. In Psalm 55:4 we have a reference to the distress caused by the "voice" ( $q \hat{o} l$ ) of the enemy, something that brings current suffering even though worse possibilities are imagined. In particular, the words of the enemy have brought the terrors of death, suggesting the strength of these words. Similarly, Psalm 56:6 speaks of the ways in which the enemies twist the words of the psalmist, something linked to a conspiracy against the poet's life (56:7). The use of words as a means of assault is particularly clear in Psalm 64, since the speech of the enemies is there explicitly compared in verse 4 to the actions of an archer shooting at a target. It is the spoken threat of the enemy in each of these cases that points to the imminence of further physical violence. However, the words themselves are described in terms of violence, suggesting that the distress caused by threatening speech represents a present experience of violence.

All of the psalms within this Gattung are marked by a common experience, where the psalmists testify to the effect of threatening speech from the enemies. Further, this threat was in and of itself perceived as an action of violence. Physical violence is imminent, but its very imminence creates a situation of present psychological distress.

\subsection{The declaration of trust}

Apart from the consistency of presentation in terms of the context of violence, it is also notable that we usually find a declaration of trust in Yahweh in these psalms. Again, this follows the model established by Psalm 3. We shall argue below that its presence is an important element in the instruction offered by the final editors of the Psalter. 
Psalm 27 poses some acute problems in terms of its literary history, but in its final form contains an opening, though general, declaration of trust in verses 1-610. Although the language used here is military, its function in the final psalm is to provide a general model of trust in Yahweh no matter what circumstances are faced. This is applied in verses 7-14 to the particular situation of the psalmist, and in particular the threats of the enemies. It is thus important that the psalmist not only recognise a general possibility of trust in Yahweh, but also that it should be addressed to the specific situation. We find this in verse 10 and more specifically in the declaration of verse 13. With the matter presented to Yahweh, trust becomes the only way forward.

Psalms 55 and 56 continue this trend, with both containing strong affirmations of trust in Yahweh. Indeed, the root $b$ ! $h$ is prominent in both. The summons in Psalm 55:23 is particularly noteworthy in that it is formulated in the imperative, and is thus a summons to other worshippers to join the poet in expressing trust, though the final declaration of trust $(55: 24)$ is once again directed to Yahweh. In Psalm 56, declarations of trust almost become a refrain followed by the psalmist, with an affirmation made in verses 4-5 that is repeated almost verbatim in verses 11-12. As with Psalms 3 and 27, a strong pattern of trust in Yahweh as protector is modelled.

Although the root bih does not occur in Psalm 143, the concept is clearly present. Here, however, the statements of trust that we find in verse 1 are linked to Yahweh's 'eñûnāh and șdeqah. These provide a foundation from which the psalmist may ask for Yahweh's protection. Trust is thus expressed, though it is less fully developed than in the previous psalms.

Only in Psalms 35 and 64 is the motif of trust not expressed directly, though it is implicit in both. In Psalm 64 we do not find an appeal for Yahweh's protection. Rather, verses 8-9 affirm that Yahweh will act against the enemies, bringing their attack to an end. Notably, the actions expected from Yahweh mirror exactly the actions of the enemies, so that the expectation of the psalmist is that the lex ralionis will be implicitly active. There is, therefore, no need for an expression of trust to be made since the wisdom-like world view effectively combines both the declaration of trust and the appeal for protection into the one part of the psalm. The very assumption of Yahweh's activity against the wicked, however, is indicative of an expression of trust. Only Psalm 35, therefore, leaves the motif of trust without explicit reference, although one could argue that the very nature of the prayer itself presumes the need to trust in Yahweh. On the 
other hand, the question of "how long?" in verse 17 could be taken as suggesting that Yahweh needs some persuasion to act"l. This needs to be balanced by the psalmist's request to be judged in accordance with Yahweh's righteousness (sedeq), which could imply some trust verse 24). In the end, though, a Gattung should not be a straight-jacket, and minor variations such as this should be expected. The element of trust in Yahweh remains, however, a central feature in these psalms.

\subsection{The appeal for protection}

The consistency that we have seen so far continues in the appeal for protection. This is as we would expect, for a situation of besetting enemies would naturally lead to an appeal for protection. Once again, though, the appeal of Psalm 3 provides a model that is largely followed by the other prayers for protection. Apart from Psalm 64, an explicit appeal for protection is made in all of these psalms. As noted above, Psalm 64 is only an apparent exception since its wisdom world view succeeds in combining the appeal for protection with the declaration of trust.

Most of these psalms include an imprecatory element within the appeal for protection. The exception to this pattern is found in Psalm 27, which provides a relatively direct prayer for protection. In verses 7-9 an appeal is made for Yahweh to hear the cry of the psalmist, with the specific appeal being for mercy. Attached to this is a request to be instructed in the ways of Yahweh (verse 11), something that is matched by the similar request in Psalm 143:10. The order of the requests in these psalms is the same, with a simple request for protection being made in 143:9. Both psalms apparently see the need to continue in the ways of Yahweh as a necessary sequel to deliverance. Psalm 143 adds to, this, however, an imprecation that asks Yahweh to destroy the enemies. What is striking is that this is sought in terms of Yahweh's hesed ${ }^{12}$. Although this may seem odd, it would seem that the request is an expression of the lex ralionis. According to verses 3-4 and 7, the actions of the enemy threatened the psalmist with death. The imprecation asks that Yahweh act as judge and make that the experience of the enemy. As with Psalm 3, retributive violence is sought that is consistent with that which has been experienced. It is also notable that no request is made for permission to personally carry out such an action. This would be inconsistent with the trust that is expressed, and the matter is accordingly left with Yahweh as judge.

Similar petitions for action against the enemy, though without the request for instruction, occur in the other prayers for protection. There are 
the natural variations that arise because of the differences in the setting of these psalms, but the pattern continues. The most extensive imprecation occurs in Psalm 35, where such a petition occurs in verses 4-8 and again in verse 26 . It is notable that the statements of verse 4 shape the first imprecation. The enemies have sought the psalmist's life (nep̃es), and the imprecation therefore asks that the enemies should experience that which they have brought into the experience of the psalmist. Just as they have plotted harm (hớc $\underline{b} \hat{e}$ ra $\bar{a} \bar{a} \hat{\imath})$ against the psalmist, so the psalmist asks Yahweh to bring harm to them. A further description of the activities of the enemies occurs in verse 7 , where a variety of hunting images are used. The imprecation of verse 8 then specifically asks that their hunting techniques be turned back on them. Similarly, the description of the activities of the enemies from verses 11-21 provides the setting for the imprecation of verse 26. Thus, the imprecation asks Yahweh to act against those who gloat over the psalmist, the act attributed to the enemies in verse 1913. The point that is consistently developed is that what is requested by the psalmist is equivalent to the actions of the enemy, either in terms of what they have done or have sought to do. The lex ralionis has thus shaped the presentation of the request.

In comparison with Psalm 35, the imprecation in the appeal for protection in Psalm 56 is muted. It is, however, still present in verses 8914. Specifically, Yahweh is summoned to bring down (hörêd) the enemies, which are here portrayed as nations through the application of cultic language ${ }^{15}$. The appeal is to God, as the divine judge, summoning him to act against the enemy in terms consistent with what they have sought to achieve against the psalmist. To bring them down is to take their life, something that is equivalent to the stated aim of the enemies with respect to the psalmist in verse 7 . Once again, the appeal has included an imprecation against the enemy, but one that is controlled by the lex talionis.

Psalm 55 provides many more difficulties, not the least of which being those caused by an extremely difficult text. Our concern here is with the fact that the psalm seems to refer to two different enemies - an undefined group of the wicked who are mentioned in verses 4 and 10b-11 and a former friend who is mentioned in verses 13-15 and 21-22. Imprecations are offered with respect to each of these foes, though the extent to which they are differentiated is not clear. However, in broad terms it would seem as if "the wicked" are responsible for a general breakdown in social order, whilst the former friend has in some way personally wounded the psalmist. We shall treat these imprecations separately, though the normal pattern will still be seen. 
The specific appeal with respect to the wicked in verse 10 asks that God destroy them. Although the verb balla' is often translated "confuse", as for example in NIV, it commonly has the meaning of a swallowing that leads to destruction ${ }^{16}$. We should translate the opening lines as "Destroy, O Lord, divide the tongue". This appeal is then directly linked to the actions of the wicked. It is their speech that has brought the terrors of death into the experience of the psalmist. The psalmist thus asks for God to act against them in terms of their speech, but also so that they are destroyed, essentially the equivalent of the terrors of death that they have brought to the psalmist. Once again, the imprecation is controlled by the lex talionis.

The actions of the former friend are more difficult to define. However, according to verses 21-22 his violence is also primarily expressed through words whose smooth exterior masks their harsh reality. Exactly what is involved in this, beyond the breach of $b$ rit Although a direct imprecation against the former friend is not made explicitly, it would seem from the fact that verses $10 \mathrm{~b}-11$ describe the actions of the wicked whilst verses 12-15 describe the former friend that the imprecation of verse 16 covers both. The impression is thus created that the former friend is among the wicked. If so, then the prayer for the death of the wicked continues to apply the principle of the lex talionis since death was the aim of the enemies, a group that includes the former friend.

The analysis of the appeals for protection and their imprecations indicates that the trust that was expressed in Yahweh in all of these psalms is applied as the basis for the petitions regarding the enemies. It is notable that in none of these psalms does the prayer include an appeal to be personally enabled to enact retribution against the enemy. Instead, the matter is committed to Yahweh as the only one able to act in a truly just manner. However, where the appeal includes an imprecatory element, the imprecation itself is shaped by the principle of the lex talionis.

\section{THE PARADIGM OFFERED BY THESE PSALMS}

Our examination of these psalms has revealed a consistent shape. As we indicated at the outset, Psalm 3 provides a basic form which is essentially followed by all the other prayers for protection. The presence of such a consistent pattern is suggestive of the possibility that the process of selection employed by the editors of the Psalter was itself intended to provide instruction. We may outline three key elements of instruction. 


\subsection{The imminence of the threat}

In each case, the psalm portrays a situation in which the protection of Yahweh is sought, though the threat has not yet reached its climax. The actions of the enemies were commonly expressed in terms of speech, but the dread that was generated, meant that the psalmists experienced this as present violence that affected them psychologically. This was primarily because the aim of the enemies was the death of the psalmist.

\subsection{The right to enact retribution belongs to Yahweh alone}

Most of these psalms expressed a desire for retribution. Where it was not expressed, it was still expected. It is notable that none of the psalmists requested permission to enact the violence of retribution themselves. Consistently, this right was ceded to Yahweh.

\subsection{The limits to retribution}

Not only was the right to retribution ceded to Yahweh, but the retribution that was sought was limited by the lex talionis. Although this usually meant the death of the enemy, the retribution sought did not go beyond those who were directly attacking the psalmist. Retribution was limited.

\section{CONCLUSION}

The examination of these psalms is suggestive of a definite editorial pattern. Those responsible for the final editing of the Psalter would appear, by their process of selection, to be indicating that the paradigm outlined above represents the appropriate response of the faithful to the experience of violence. The editors would appear to be suggesting that those who experience violence are not to act so as to seek their own vindication. Instead, their only true recourse is to continue to trust in Yahweh as the one who can and does act justly, even when present experience does not seem to bear this out.

\section{NOTES:}

1 This paper is part of a PhD thesis that was submitted in the department of Old Testament, University of Pretoria, with prof W S Prinsloo as supervisor.

2 For a convenient summary of this trend, see W S Prinsloo, "Die psalms as samehangende boek", NGTT 36 (1995), 459-469. 
3 S Mowinckel, The psalms in lsrael's worship, Vol 1, Oxford 1962, $219 \mathrm{ff}$.

4 H Birkeland, Die Feinde des Individuums in der israelitischen Psalmenliteratur, Oslo 1933 and H Birkeland, The evildoers in the book of psalms, Oslo 1955.

5 Mowinckel, Vol 1, op cit, 220.

6 On the detail supporting this structure, see W S Prinsloo, Die psalms leef!, Pretoria 1991, 1ff. The suggestion of J P M van der Ploeg, Psalmen I, Roermond 1973,47 , that verse 9 be regarded as a gloss, is unnecessary.

7 D G Firth, "Responses to violence in some lament psalms of the individual", Skrif en Kerk 17/2 (1996), 317-328.

8 Against H-J Kraus, Psalms I-59, Minneapolis 1988, 140, it is not necessary to see any indication of a nocturnal vigil in the temple in verse 6. It is Yahweh's sustenance that is stressed.

9 It is notable that hamass is attributed to the false witnesses by both texts.

10 On literary grounds, it is often argued that Psalm 27 is a composite. A convenient summary of the arguments in favour of the partition may be found in A A Anderson, Psalms (2 vols), Grand Rapids 1972, 219f. The position taken here is that although verses 1-6 may well have been an independent composition, verses 7-14 never existed apart from them. See F Lindström, Suffering and sin: Interpretations of illness in the individual complaint psalms, Stockholm 1994, 141ff and D G Firth, Responses to violence in lament psalms of the individual, (unpublished Ph D thesis), University of Pretoria 1996, 92ff. It is thus legitimate to examine the psalm as a unity.

11 W Brueggemann, The message of the psalms, Minneapolis 1984, $63 \mathrm{f}$.

12 It is notable that the request for a word from Yahweh in verse 8 is also grounded in Yahweh's hiesed.

12 The root smh occurs in both instances.

13 These verses pose a number of text-critical issues, though the thrust of the imprecation is clear. On the text, see G R Driver, "Psalm LVI. 9 "Thou tellest my wanderings'", Journal of Theological Studies 21 (1970), 402-403 and M E Tate, Psalms 51-100, Dallas 1990, 67.

14 Anderson, op cit, 423.

15 Tate, op cit, 52. 